\title{
In Spaces of Marginalization: Dispossession, Incorporation, and Resistance in Bolivia
}

\author{
Brent Z. Kaup \\ College of William \& Mary \\ bzkaup@wm.edu
}

\begin{abstract}
Recent scholarship conceptualizing primitive accumulation as an ongoing process in global capitalism has noted the difficulties faced in bringing struggles against exploitation and dispossession together. While some scholars suggest that an 'organic link' exists between these conflicts, they have yet to clearly specify the conditions and mechanisms through which such a link can form. Examining cases in Bolivia at the turn of the twenty-first century, I argue that struggles against exploitation and dispossession do not merely converge when facing a common oppressor, but also as the changing forms and geographies of exploitation and dispossession bring people together in more proximate locations. I illustrate that the changing means through which Bolivia was incorporated into the global economy enhanced levels of marginalization and subsequently resulted in patterns of migration that led to a convergence of peasant and proletarian struggles. As both segments of Bolivian society were excluded from the country's major economic sectors, they migrated to the places where they thought they could best satisfy their livelihood needs. But as people continually struggled to meet these needs, these places became spaces of marginalization, and eventually, spaces of resistance.
\end{abstract}

Keywords: primitive accumulation, incorporation, Bolivia, peasant-proletarian struggle

Bolivia's rich natural resource base has long attracted international interest. Bolivians have continually been dispossessed by global hegemons, neighboring countries, and even by some of their own people for their country's silver, guano, rubber, tin, and natural gas. But recently, struggles against this dispossession have taken a new form. Whereas Bolivia's campesinos and workers historically had different demands and were often pitted against one another, over the past three decades these two factions have frequently taken to the streets together in common protest. But what led to this convergence of Bolivia's peasantry and proletariat in struggles for social change?

To answer this question, I engage and extend contemporary theories that see primitive accumulation as a continual process within the expansion of global capitalism. While the divides between the peasantry and proletariat have long puzzled scholars of development, social movements, and social change (e.g., Wolf 1969; Amin 1977, 1974; Wallerstein 2000, 1979), the question of how to bring them together has found renewed interest amongst scholars examining

Copyright (C2013, American Sociological Association, Volume XIX, Number 1, Pages 108-129, ISSN 1076156X 
resistance to primitive accumulation in the contemporary neoliberal era (e.g., Harvey 2003; Moore 2004; Glassman 2006; Hough and Bair 2012). Bringing this work into closer dialogue with world-system theorizations of incorporation, I suggest that scholars should see ongoing forms of primitive accumulation not only as a response to crises of overaccumulation, but also as evidence of shifting global power structures that can result in the reformation of global trade networks and the restructuring of local economies. Taking such an approach, I argue that struggles against exploitation and dispossession do not merely converge when facing a common oppressor, but also when the changing forms and geographies of exploitation and dispossession bring people together in common places.

To make this argument, I examine Bolivia's changing role in the global economy from being a provider of tin to being a provider of natural gas. I illustrate that the changing means through which Bolivia was incorporated into the global economy enhanced levels of marginalization and subsequently resulted in patterns of migration that led to a convergence of peasant and proletarian struggles. As both segments of Bolivian society were excluded from the country's major economic sectors, they migrated to the places where they thought they could best satisfy their basic needs. But as people continually struggled for their livelihoods, these places of migration became spaces of marginalization, and eventually, spaces of resistance.

In this study, I deploy a variant of the extended case method (Burawoy 1991). I bring interview and ethnographic data, government statistics, archival research, and primary document and media analysis from Bolivia into conversation with existing theories of primitive accumulation, accumulation by dispossession, and resistance. Focusing on Bolivia, I am not attempting to draw attention to an understudied case. Indeed, there has been a recent proliferation of scholarship about contemporary Bolivia and its social movements, some of which has drawn upon theories similar to those engaged herein (e.g., Kohl and Farthing 2006; Hylton and Thomson 2007; Spronk and Webber 2007; Webber 2011). Instead, my intention is to better historicize resistance to continual forms of primitive accumulation by more closely accounting for the relationship between global economic change and local acts of dispossession. By doing so, I seek to provide a deeper understanding of some of the causal mechanisms driving social uprising and socioeconomic change in Bolivia - and elsewhere - over the past three decades.

\section{Conceptualizing Struggles Against Economic Oppression}

The system of capitalism is based upon the imperative of continual accumulation and economic growth. This accumulation and growth is most often achieved by gleaning and reinvesting profit accrued from a worker's surplus labor. Through what Karl Marx (1867) called expanded reproduction, such a profit-making strategy is often perceived as the principal means of capital accumulation and economic growth in advanced capitalism. But capital accumulation and economic growth can also be achieved in another way. Instead of profiting from the products of a worker's labor, capitalists can also profit through what Marx called primitive accumulation. Primitive accumulation is most often conceptualized as the process through which peasants were forced off the lands upon which they subsisted. Divorced from their own means of production, these peasants moved from being primary producers to wage workers. In the words of Marx (1867), such a process transformed "the social means of subsistence and of production into capital" and turned "immediate producers into wage laborers." The enclosure and privatization 
of land provided capitalists with their initial stock of capital and the removal of peasants from the land provided capitalists with an initial labor supply.

Marx's primary focus was upon expanded reproduction and the class struggles resulting from it. While he recognized the brute violence that often accompanied processes of primitive accumulation, he was less than sympathetic to the peasant way of life. He saw resistance to primitive accumulation as a regressive attempt to cling to a livelihood strategy that he believed had little potential to ease the everyday trials and tribulations of human existence. In contrast, Marx saw resistance to expanded reproduction as potentially liberating. They could lead to higher wages, better working conditions, and the eventual usurpation of the capitalist class, as workers fought for control of the means of production.

More recently, scholars have drawn greater attention to ongoing forms of primitive accumulation. Attempting to disrupt depictions that posit primitive accumulation as occurring merely in the early stages of capitalism, such scholars assert that primitive accumulation is a continual process through which to relieve crises of overaccumulation (Perelman 2000; Harvey 2003; Glassman 2006). What this continual form of primitive accumulation, or "accumulation by dispossession," does is "release a set of assets (including labor power) at very low (and in some instances zero) cost. Overaccumulated capital can seize hold of and immediately turn them to profitable use" (Harvey 2003: 149). As per Marx's conceptualization of primitive accumulation, accumulation by dispossession is a way to accumulate capital without the use of wage labor, through 'extra-economic' means. But scholars move beyond seeing accumulation by dispossession as the mere capture and enclosure of the means of subsistence and other previously non-commoditized assets. The processes are more dynamic. Through accumulation by dispossession, profit can also be made by expropriating and/or de- and revaluing already commoditized assets.

For a number of scholars of accumulation by dispossession, such a process underpins contemporary globalization and neoliberal forms of capitalism. Suffering from crises of overaccumulation, transnational investors have sought to capture and enclose new tracks of land and natural resource reserves that previously were insulated from or rested outside of global commodity circuits. This can be seen with the end of the ejido in Mexico in 1991, the ongoing privatization of water throughout the globe, and the pricing of air and carbon through the creation of carbon markets. In addition, such investors have sought to push already commoditized assets into apparent disarray, buy them at low prices, and then return them to the market in an 'improved' form. This is evident in the privatization of state owned productive enterprises throughout the world and the ongoing transfer of devalued assets (land, houses, retirement funds, etc.) from the general masses to the rich after the global financial crisis of 2008.

In conjunction with these observations, a number of scholars argue that while accumulation by dispossession can follow Marx's theorization of primitive accumulation and result in the creation of wage laborers, there is no necessary reason it must (Glassman 2006: 615616; Prudham 2007: 411). Throughout history, capitalists have not always sought to include the labor of everyone in the work process, as a reserve army of labor can drive down costs (e.g., Wallerstein 1979; Wolpe 1980). People have also actively and successfully resisted proletarianization, not wanting to subject themselves to the poor working conditions and lifestyles available to entry-level wage laborers (e.g. Scott 1976, 1985). And some commodities can be 'made' or expropriated without directly displacing people from or disrupting their everyday livelihood activities (e.g., McCarthy 2004; Prudham 2007). 
Seeing primitive accumulation as accumulation by dispossession in some ways challenges traditional Marxist notions of class struggle and social change. If accumulation by dispossession is ongoing and does not always result in the creation of wage laborers, the objects and means of class struggle may differ. While the proletarianized have historically focused their struggles upon improving the lives of workers and the conditions in the workplace, the dispossessed have engaged in a myriad array of struggles over everything from the land upon which to subside (e.g., Martin 2005; Wolford 2005), to trade and financial rules (e.g., McCarthy 2004), to the basic necessities of life such as water and air (e.g., Budds 2004; Perreault 2006).

A range of scholars have noted that the vast number and heterogeneity of struggles against accumulation by dispossession pose difficulties for contemporary social movements (e.g., Harvey 2003; Glassman 2006). On the most basic level, the sheer quantity of these struggles and their different objectives make it difficult to draw connections between them. Moreover, as Harvey (2003: 162-180) asserts, Marx's original 'reticence' to see anything progressive about struggles against primitive accumulation seems to still exist today. In particular, a divide remains between the participants in struggles against expanded reproduction and accumulation by dispossession. The traditional focus of workers upon the struggle between capital and labor has excluded many from the benefits they receive (or at least once did receive). In turn, this has led the dispossessed to see labor, and in many instances the state upon which labor depends, as less relevant to achieving their goals.

Despite these differences, Harvey (2003) insists that struggles against expanded reproduction and accumulation by dispossession are "organically linked." But if an organic link exists between such struggles, how can they be brought together in practice? What factors allow this organic link to be realized? While Harvey (2003: 179) notes that "the umbilical cord between the two forms of struggle that lies in financial institutional arrangements backed by state powers (as embedded in and symbolized by the IMF and the WTO) has been clearly recognized," he does not explain what this umbilical cord can possibly be made of. In other words, the conditions and mechanisms through which struggles against expanded reproduction and accumulation by dispossession can come together on the ground are not theorized. To better understand the convergence of such struggles, I suggest that scholars should draw more closely from world-systems perspectives that not only see primitive accumulation as ongoing and dynamic process, but also see incorporation into the global economy as an ongoing and dynamic process.

\section{A World-Systems Approach to Conceptualizing the Convergence of Struggles Against Economic Oppression}

World systems scholars have long observed how people and places are brought into global circuits of production. For Immanuel Wallerstein (1989) and others (e.g., Arrighi 1979; Sokolovsky 1985), incorporation followed Marx's ideas of formal and real subsumption. Formal, or what some have called "nominal," incorporation occurs when a place is brought into global circuits of capital accumulation but the existing means of production and reproduction remain largely unchanged. For example, when the conquistadors claimed Latin America for the Spanish crown, they forced local peoples to work in the mines. However, the livelihood strategies of these people remained largely dependent upon subsistence farming. They were nominally incorporated into the global economy in that the conquistadors and Spanish crown exercised a 
level of domination over their lives and territory, but their subsistence livelihood strategies remained largely the same. In contrast, real, or what some have called "effective," incorporation occurs when a place is brought into global circuits of capital accumulation and the existing means of production and reproduction cease to be dominant and "disintegrate qua systems." For example, after forced labor regimes were eliminated in Latin American mining activities, increasing numbers of people worked in the mines for a wage. As this occurred, the systems of agriculture and trade in some places changed so that those primarily working in the mines could purchase their everyday subsistence needs. These people were effectively incorporated into the global economy as the very means of societal organization shifted.

While a number of world-systems scholars see effective incorporation as the moment in which places become "hooked" into the global economy in ways that are difficult to escape (Wallerstein 1989: 130), this does not mean that incorporation should be seen as a static process. As Denis O'Hearn argues, places are continually incorporated, disincorporated, and reincorporated into the world-system. As this occurs, places can move from having "more to less proletarian social relations of production" (O'Hearn 2001: 16). In other words, the levels and means of economic oppression experienced by local peoples often change with global power shifts. Exploitation, the incorporation of a person into the global economy for their labor, can be deepened if new forms of production and reproduction require increasing quantities of labor. Exploitation can give way to marginalization, or the outright exclusion of a person from the global economy, if new forms of production and reproduction require less labor. And marginalization can be deepened if the already marginalized see access to what few resources they have - resources such as access to the commons or ownership over small parcels of land taken or spoiled. ${ }^{1}$

At first glance, it seems as if the observations made by scholars of accumulation by dispossession can account for the observations made by world-systems scholars. As powerful countries and transnational corporations seek to resolve crises of overaccumulation, they incorporate new people and places into the global economy. If such people and places do not exist, powerful countries and transnational corporations seek to disincorporate and reincorporate them. Upon disincorporation, the value of the disincorporated's assets fall and the powerful countries and transnational corporations seek to acquire them at discounted rates. They then reincorporate and sell the assets they acquired at costs above what they paid for them. But seeing accumulation by dispossession in this way overlooks a number of key insights made by worldsystems scholars that hold significant implications for understanding why and how struggles against accumulation by dispossession and expanded reproduction can converge.

First, seeing accumulation by dispossession largely as a means to resolve a crisis of overaccumulation can cause scholars to overlook the broader global economic shifts happening during crises of overaccumulation and thus who is actually benefitting from acts of dispossession. As Giovanni Arrighi argues, crises of overaccumulation have been recurrent throughout the history of capitalism and often mark the descent of one hegemon and the rise of another (1994, 2005; see also Braudel 1984). Taking this into account, while some capitalists do indeed utilize processes of accumulation by dispossession to create or access new sites in which to invest stagnant capital, other capitalists utilize them to access necessary human and material inputs and/or to merely increase profits. Seeking to overcome relative scarcity, ascending powers

\footnotetext{
${ }^{1}$ These definitions of exploitation and marginalization are based on O'Hearn's (2001) descriptions of exploitation and marginalization in the world-system. O'Hearn distinguishes between the two by drawing upon Wright's (1985) distinctions between exploitation and economic oppression.
} 
and aligned transnational firms may utilize processes of accumulation by dispossession to secure supplies of labor and/or raw materials.

Recognizing global power shifts allows scholars to consider a second insight made by world-systems scholars. Ascending global powers seeking to satisfy their labor and raw material needs face different spatial constraints than existing or falling global powers. In particular, rising global powers are often more easily able to incorporate raw material and labor supplies from places that are closer to the point of production and/or use. As a result, global economic and hegemonic shifts can result in a reorganization of global trade networks and processes of de- and reincorporation. As Stephen Bunker (1984: 1019) argues: "Different regional levels of development result from the interaction between changing world demand for specific commodities and the local reorganization of modes of production and extraction in response to new or changing market opportunities or pressures."

The importance of recognizing the needs of rising global powers becomes even more evident when accounting for a third and related observation made by world-systems scholars. A location's de- and reincorporation into the global economy according to the needs of ascending powers affects local people's livelihood strategies. In other words, as places' roles in the global economy change, so do the demands for labor. On occasion, the ability to earn a living may decline in one place or industry and rise in others. Those who can, subsequently migrate to places of perceived opportunity (Bunker 1984, 1985). However, as Anibal Quijano (1983: 79; see also 1970) observes, the global expansion of circuits of capital accumulation can result in "a growing incapacity to absorb and reabsorb cyclically an increasingly large part of the inactive labor force." Indeed, as new global powers rise, they not only source different things from new locations, they use different methods to do so (O'Hearn 2001, 2005; Bunker and Ciccantell 2005). In a world in which the last remaining remnants of the population are still being pushed into the global labor force and mechanization continues to increase, the ranks of those marginalized in some places within global commodity circuits have grown.

These three insights made by world-systems scholars change our understanding of the convergence of contemporary struggles of the oppressed. People are not merely struggling against exploitation and dispossession, but against the changing forms and geographies of exploitation and dispossession. In the contemporary era, most people and places have in some way - be it nominally or effectively - been incorporated into the global economy. But as rising powers alter global trade routes to better satisfy their needs, people and places in the periphery become de- and reincorporated into the global economy. In the process, their established livelihood strategies are disrupted, often in ways that make it more difficult to meet their daily needs. As people subsequently migrate to places of only perceived opportunity - to spaces of marginalization - workers and peasants alike have often been forced to eke out a livelihood together. And in these spaces of marginalization, struggles against exploitation and dispossession can converge.

We can see these processes over the past three decades in Bolivia. Peasant and proletarian struggles slowly converged. As power in the global economy began to shift away from the United States and as ascending states sought to satisfy their material needs, Bolivia was de- and reincorporated into the world system in a way that affected both peasants and workers. Moving from being incorporated into the global economy for minerals to being incorporated for natural gas, growing segments of the Bolivian population became marginalized. Removed from their livelihood strategies, Bolivia's peasants and workers migrated to places where they believed they could earn a living and satisfy their everyday needs. But still excluded from 
Bolivia's major economic sectors, they forged an organic link that brought them together in the streets.

\section{Incorporation in the Long Twentieth Century}

In the early $1900 \mathrm{~s}$, Bolivia's role in the global economy shifted. While the country had long been a source of silver and rubber, it rapidly became incorporated into the global economy for another of its underground riches - tin. Global tin demand had been increasing since the 1850 s as some of the most easily accessible supplies in the Cornwall mines of the United Kingdom were tapping out. By the end of the century, the price of tin ore had experienced a tenfold increase. With the completion of a railroad from Bolivia's mining regions to the Pacific Ocean in 1892 and the development of new smelting technology that made processing tin contained in hard rock ores possible, the country's tin supplies became highly attractive and competitive in the global marketplace (Contreras 1993). Such changes substantially increased the amount of tin extracted in Bolivia. In 1880, less than 1,000 tons of tin were extracted in the country. By 1910, this had increased to more the 20,000 tons. During this time, tin became Bolivia's top export and the country's share of global tin production increased from less than 2 percent to more than 20 percent (Ayub and Hashimoto 1985).

The change in Bolivia's incorporation into the global economy came as a shift in global power was occurring. Great Britain's power was slowly being yielded to the United States. This was evident in the global trade and consumption of tin. Great Britain was the largest global consumer of tin until the early twentieth century. However, a number of smelters were built in the United States during World War I, and by the 1920s the United States was importing over 50 percent of the global tin supply, a significant share of which came from Bolivia (Warshow 1927). The United States' demand for tin dramatically decreased during the Great Depression. But its demand for Bolivia's tin rebounded during World War II, particularly after the Japanese cut off Allied access to the tin supplies of Southeast Asia (Griess 1951).

In the early years of the post-war era, the extraction of tin in Bolivia again rapidly declined. The end of the war decreased global demand for tin. In addition, a glut of tin flooded the market as southeast Asian tin producers reentered global tin commodity circuits and the United States began to sell-off tin from its strategic wartime stockpile. In Bolivia, the decreasing market for tin occurred amidst local social unrest. Segments of the country's upper and middle classes began to push for democratic rule and an end to the tin oligarchy's control over the state. Tin miners formed more radical unions and began to forcefully struggle for better wages and improved working conditions. And campesinos started to demand greater access to land. Struggling to meet their livelihood needs and deprived of opportunity, the common angst of these groups seemed to align towards the end of the $1940 \mathrm{~s}$.

In 1952, revolutionary insurrection resulted in the eventual nationalization of the mines and a process of land reform. Through this nationalization, the miners secured a level of worker control within the newly formed state-owned mining company - the Corporación Minera de Bolivia (COMIBOL). Through agrarian reform, over 5 million hectares of land were redistributed in less than a decade. However, the gains made by both Bolivia's miners and campesinos proved to be bittersweet. The miners inherited an industry in which technological investment had not been made in decades. With a decreasing global demand for tin and a cashstrapped state unable to upgrade the extraction technology in the mines, COMIBOL found it 
difficult to turn a profit. At the same time, while many campesinos benefitted from the agrarian reform program, they often only received relatively small plots of land. The majority of Bolivia's land thus remained in the hands of latifundia owners.

But in the decades following the revolution, the differences between the struggles of Bolivia's workers and campesinos became apparent and whatever illusion of convergence that existed quickly disappeared. Whereas Bolivia's miners were in fairly constant struggle with the state, the country's campesinos seemed somewhat appeased. As global tin prices and extraction levels remained stagnant throughout the $1950 \mathrm{~s}$ and $1960 \mathrm{~s}$, so did COMIBOL's profits. The miners' case for improved wages and working conditions thus rested on shaky ground. In contrast, the state was able to more easily satisfy the country's campesinos. While land ownership remained highly concentrated, the small parcels of land granted to the campesinos allowed them maintain a subsistence lifestyle and sell their surpluses in local markets. This allowed the state to gain the support of campesinos and pit them against the miners.

While global tin prices and demand increased again in the $1970 \mathrm{~s}$, the commodity boom was quickly followed by a commodity bust. The tin market began to collapse in 1980 and global prices fell by close to 300 percent in less than five years (USGS 2011). Global tin flows also began to change, as companies from the United States and Europe began to outsource and manufacture increasing amounts of goods in cheaper places throughout the world and rivaling global powers began to challenge for global dominance. Since tin made up close to half of Bolivia's total export value, the loss of demand for tin from the United States and Europe brought Bolivia's incorporation into the global economy as a tin producer to a rapid end (CEPALSTAT 2011; ITRI 2011).

\section{Dispossession and Disincorporation}

By the mid-1980s, Bolivia was in the middle of an economic crisis. The collapse of the tin market severely hampered one of the state's primary means of acquiring foreign exchange. At the same time, the International Monetary Fund and World Bank had also refused to lend money to the Bolivian state unless it prioritized the repayment of foreign debt (World Bank 1983; Sachs 1987). Unable to meet its financial needs, the newly elected leftist government undertook a form of quantitative easing by increasing its money supply. The measure failed to resolve the crisis, and the government was forced to hold early elections. In August 1985, a burgeoning segment of the elite that favored private enterprise took control of the state and embarked upon a path of systematic dispossession. But the major benefactors of such dispossession were not from the United States or Europe. Indeed, the profits from Bolivia's natural resource wealth increasingly filled the pockets of internal elites.

With COMIBOL suffering from the fallen price of tin, Bolivia's mineral reserves became ripe targets for dispossession. In the 1952 nationalization of Bolivia's mines, the state granted COMIBOL the rights to country's most lucrative tin mines and guaranteed the company exclusive rights to 80 percent of the country's mineral reserves (Ayub and Hashimoto 1985; Morales and Espejo 1994: 21-22). However, a small private mining sector survived and became quite profitable selling zinc, antimony, tungsten, and lead (Fox 1985; Contreras and Pacheco 1989). The private mining sector's more diversified mineral portfolio allowed it to better withstand the collapse of the tin market. And with the rise of a government favoring private 
investment, the internal private mining elite pushed for the end of COMIBOL and its rights over the majority of Bolivia's mineral reserves.

As part of a broader policy package known as the New Economic Policy (NEP), the Bolivian state put forward a plan to "rehabilitate" the mineral sector. The rehabilitation entailed ending COMIBOL's near monopoly over the mining sector, granting private investors long-term leases to mineral reserves, eliminating the centralized mineral marketing bank, and giving investors the rights to commercialize the minerals they extracted on their own (GOB 1985a, 1985b; Seyler 1989: 134). The result was the tacit privatization of the sector. Given the rights to some of COMIBOL's most lucrative reserves, private Bolivian mining firms more than doubled their investments. As they did, their share in the production value of the country's minerals increased from 17 percent in 1980 to 57 percent by 1990 and the total value of their mineral exports increased from US\$64.768 million a year to US\$157.6 million a year (Ministerio de Minería y Metalurgia 2011). But the rehabilitation of the mining sector resulted in neither an increase in mining activities nor an increase in total mining revenue. While extraction levels rebounded from their lows in 1985, average annual extraction rates over the following decade remained below what they were in the 1970s (CEPALSTAT 2011). Indeed, the internal private mining elite merely made what were previously the state's profits its own (see Figure 1).

Figure 1: Percent Share of Bolivia's Total Mineral Export Value by Subsector, 1980-1990

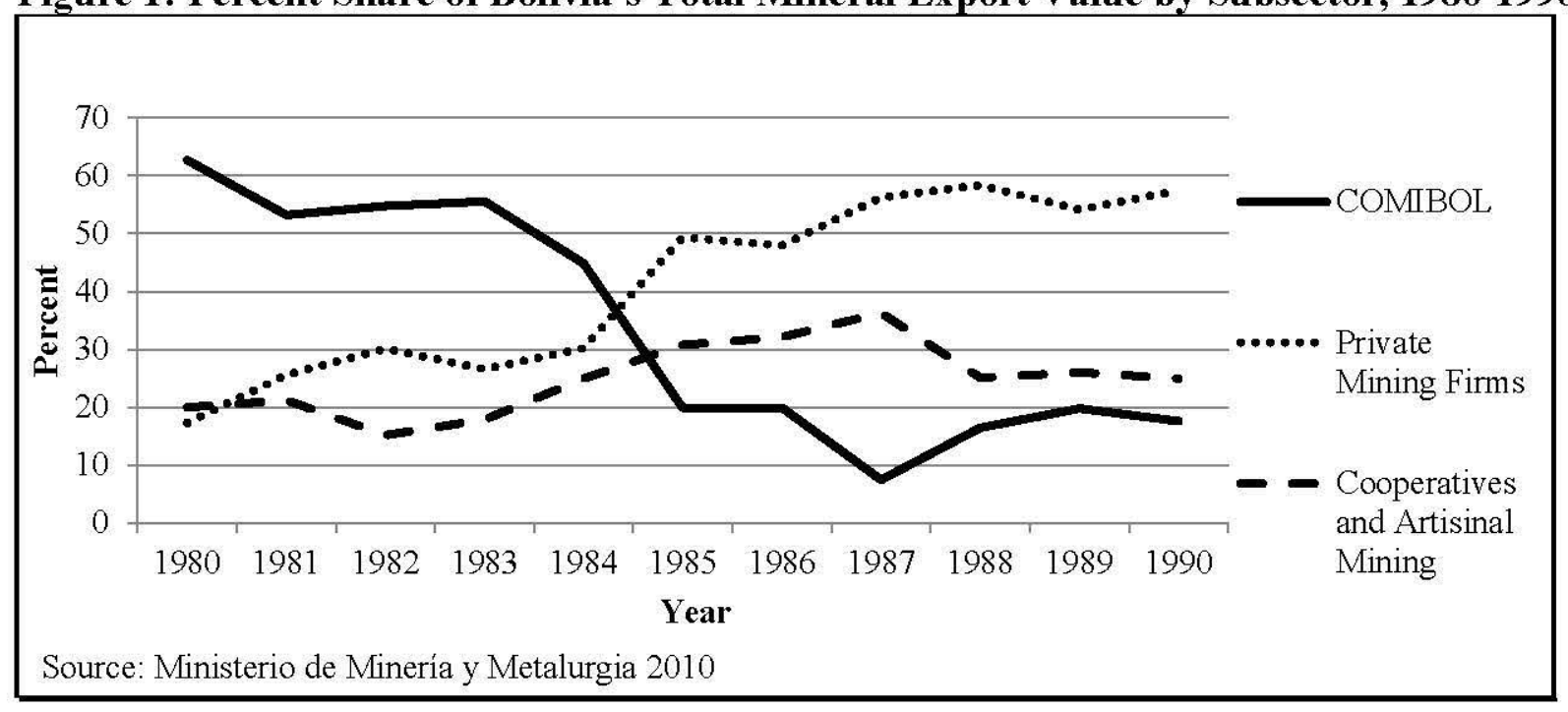

While Bolivia's internal mining elite prospered, its miners found themselves unemployed or pushed into precarious work situations. As part of the mining sector's rehabilitation, the state cut COMIBOL's workforce by close to 75 percent in less than two years. Between 1984 and 1986 , the number of miners working for COMIBOL decreased from 29,803 to 7,500 . While some of these miners regained employment in the sector with private firms or by forming worker cooperatives, most did not. The private mining sector tended to use more technologically advanced means of production and thus had a lower demand for workers. In addition, with private companies being granted the rights to some of Bolivia's richest mineral reserves, those who formed cooperatives were frequently left working mines that were nearly tapped out and/or contained low-grade ore. And while COMIBOL lacked the funds for frequent technological upgrades, the cooperatives had even less access to capital and credit, leaving them with outdated 
and inferior equipment (Fox 1985). As a result, miners who formed cooperatives made less money and received few - if any - of the benefits they once did working for COMIBOL.

The NEP also adversely affected Bolivia's campesinos by opening segments of the country's economy to private investment and liberalizing trade. In the agricultural sector, the state eliminated agricultural subsidies, ended restrictions on the quantity of agricultural imports, and lowered agricultural tariff rates (Morales 1990). Since Bolivia's neighbors and other countries subsidized agricultural production, large quantities of agricultural imports flooded local markets, making it difficult for campesinos to sell their agricultural surpluses in local markets at competitive rates.

Thus, both miners and campesinos struggled to meet their livelihood needs in the wake of the the international tin market collapse and the introduction of the NEP. Export levels in the mining sector remained stagnant and decreased to Bolivia's previously dominant trading partners - the United States and to a lesser extent Japan. While exports of zinc increased in the late 1980s, such increases did not make up for the loss in demand for the country's other minerals (see Figure 2). Economic growth in general mildly rebounded in the late $1980 \mathrm{~s}$, but such growth came only after Bolivia's mineral wealth and riches had been significantly devalued.

Figure 2: Bolivia's Mineral Exports, 1970-1990



\section{Dispossession and Reincorporation}

In the early $1990 \mathrm{~s}$, another commodity from the Bolivian underground began to attract international interest: natural gas. First nationalizing its oil and natural gas in 1936, Bolivian control over its hydrocarbons had largely rested in the hands of the state-owned company, Yacimientos Petrolíferos Fiscales Bolivianos (YPFB). Gulf Oil briefly became the dominant actor in the country's hydrocarbon sector in the $1960 \mathrm{~s}$, but a second nationalization in 1969 gave YPFB control over the private company's assets. Historically, oil and natural gas played a lesser role in the Bolivian economy than minerals. Natural gas briefly became the country's number one export during the $1980 \mathrm{~s}$, but this was more due to the collapse of the mineral market than any increase in the volume and export of natural gas. However, an increasing demand for energy in Brazil - Bolivia's eastern neighbor and a rising global power - drew the attention of 
transnational oil and natural gas companies. With a nationally owned hydrocarbon company that found it increasingly difficult to expand its operations after its earnings were redirected towards central state coffers in the 1980s through the NEP, Bolivia's oil and natural gas reserves were another ripe target for dispossession.

In 1993, the Bolivian state did to YPFB what it did to COMIBOL in the decade prior. Through a policy package known as the Plan de Todos (Plan for All), the Bolivian state granted private investors long-term leases to oil and natural gas reserves and gave them the rights to commercialize the hydrocarbons they extracted. However, the state also sought to largely remove YPFB from the sector. While COMIBOL continued to extract minerals even after private investors were allowed into the mining sector, the state auctioned off YPFB's assets to private companies and thus removed it from all hydrocarbon extraction and transport activities. The new investors in Bolivia's hydrocarbon sector also differed from those in Bolivia's mineral sector. Whereas the internal private mining firms grew to dominate mineral extraction in the $1980 \mathrm{~s}$, there were few internal private hydrocarbon firms. As a result, transnational hydrocarbon firms became the dominant actors in Bolivia's oil and natural gas extraction and transport activities (Kaup 2013).

In contrast to Bolivia's internal mining firms, the transnational hydrocarbon companies were not merely interested in transferring the profits once accrued by YPFB to their own pockets. Instead, they were interested in strategically expanding the market for Bolivia's natural gas. In particular, the Brazilian state-owned company Petrobras was interested in reincorporating Bolivia into the global economy to serve the demands of its home country. Brazil had already sought to import Bolivia's natural gas into its energy matrix prior to the Plan de Todos in an agreement with YPFB. However, after the sector was privatized, Brazil negotiated to double the amount of natural gas it sought to import from Bolivia. After doing so, Petrobras became the largest investor in the sector. While transnational hydrocarbon firms as a whole invested over US $\$ 3.435$ billion between 1997 and 2006, Petrobras alone invested over US\$1.5 billion. These investments led to over a fivefold increase in the amount of natural gas exported from Bolivia, nearly all of which went to Brazil (Campodónico 2007).

Despite the increase in the production and export of natural gas from Bolivia, employment in the hydrocarbon sector in some ways resembled that of the mineral sector. The state asserted that opening the country's hydrocarbon sector to private investment would both make it more efficient and eventually lead to greater job creation and salary increases. However, the opposite proved to be true. As a YPFB union representative noted when speaking of the Plan de Todos:

We thought that there would be an injection of money that favored the Bolivian state, the business, and the workers. But lamentably the only ones that it favored were some people in the government and the transnationals. And those really affected were the workers. Many thousands ended up in the streets (personal interview).

Whereas YPFB had sought to continually invest and employ people in both exploration and extraction activities, the transnational hydrocarbon companies that entered after the sector was privatized largely only invested in extraction activities. Given the materiality of hydrocarbon extraction, once an oil and natural gas reserve is found and a well-head is put on, very little labor is needed to keep the oil and natural gas flowing. When the transnational extraction firms did 
invest in exploration, they usually sub-contracted out the activities. As another YPFB employee explained:

Before, Yacimientos [YPFB] had 1800 people here. There were 200 people in perforation, 200 in production, etc. But what happened? The new businesses that entered, they didn't do perforation and if they had to perforate they got somebody else to do the job (personal interview).

And the "somebody else" was the subcontractor who bid the lowest. When private energy firms first entered Bolivia and expanded the extraction activities in the sector, there was more work than workers and thus plenty of opportunity. But after the most easily accessible reserves in Bolivia were tapped, such opportunity decreased. The employment and wages of workers in the hydrocarbon sector became contingent upon fickle demand. Talking about one of his employees, a president in a sub-contracting service company summed up the state of the situation after the initial boom: "One of our technicians ran a chicken farm. He came and worked for us whenever we had a job because the money was really good, but chickens are a bit more stable" (personal interview). As with workers in the mineral sector, workers in the hydrocarbon sector found themselves in highly unstable employment situations.

In the late $1990 \mathrm{~s}$ and early $2000 \mathrm{~s}$, Bolivia was thus reincorporated into the global economy as a rising global power, Brazil, tapped the country's energy supplies. However, the terms of reincorporation - with a commodity requiring minimal labor for production - left the majority of Bolivians dispossessed and marginalized in global commodity circuits. In response, Bolivia's dispossessed began to form the organic links that would bring them together in the streets.

\section{Forging Organic Links in Spaces of Marginalization}

As Bolivian workers and campesinos alike found their livelihood strategies undermined, they increasingly began to migrate to places of perceived opportunity. For many, these places were the outskirts of Bolivia's largest cities of La Paz, Cochabamba, and Santa Cruz de la Sierra. Between 1976 and 1992, all three nearly doubled in size (INE 2011). ${ }^{2}$ But while these urban migrant destinations served as beacons to those affected by processes of dispossession, many were merely spaces of marginalization. Migrants found the cities bursting with displaced workers. With a surplus supply of labor and minimal labor regulations, employers with jobs offered low wages and little or no security or benefits (Arze and Kruse 2004). Many of the jobs were in the informal economy. After the introduction of the NEP, informal employment in urban areas rarely dropped below 50 percent of the economically active population, and estimates at the turn of the twenty-first century put close to 70 percent of the working population in the informal economy (Rossell 1999; Rojas and Guaygua 2002). The influx of migrants to urban destinations, combined with poor city planning and a lack of funds, forced many into precarious living conditions. Developers often failed to follow zoning regulations and constructed neighborhoods that had little or no access to basic services (Kohl and Farthing 2006; Arbona 2007).

\footnotetext{
${ }^{2}$ By way of comparison, the Bolivian population grew by 40 percent during this time.
} 
The sprawling city of El Alto that adjoins La Paz served as a textbook example of a space of marginalization. Starting in the early $1980 \mathrm{~s}$, tens of thousands of miners and campesinos migrated to the city. The first wave of campesinos arrived as a two-year drought starting in 1982 forced subsistence farmers to seek out an alternative means to earn a living. These campesinos were joined in 1985 by miners who lost their jobs at COMIBOL and later by a new wave of campesinos who, as we saw above, had lost their means of earning additional income by selling surpluses in local markets after the introduction of the NEP. In El Alto, the migrants found poor working and living conditions. In addition to precarious work conditions, 65 percent of people in El Alto lived in places with no indoor plumbing, and 94 percent of roads were unpaved (Arbona 2007).

But as they attempted to resolve the problems they faced, the city's miner and campesino migrants slowly turned El Alto into a common space of resistance. Residents in urban migrant hubs converged in neighborhood groups under the banner of the Federación de Juntas Vecinales (FEJUVE). In 1989, El Alto's expanding population had organized 166 juntas vecinales. By 2005, this number had more than doubled (Kohl and Farthing 2006:160). The groups sought to have their basic livelihood needs met and struggled for services such as electricity, sewage, and water. They also sought secure land titles and other social services (Gill 2000: 160). And by focusing upon the common needs of people and shared forms of oppression, FEJUVE and similar groups in urban migrant places gradually began to form the organic links necessary to overcome the traditional peasant-proletariat divide in Bolivia.

Some rural areas in Bolivia also became places of perceived opportunity in the $1980 \mathrm{~s}$ and 1990s. While the elimination of import tariffs with the introduction of the NEP threatened the livelihood strategies of many people in rural areas, one Bolivian agricultural commodity went largely unaffected by the changes: coca. A number of miners who lost their jobs at COMIBOL thus joined campesinos looking for land and opportunity in the coca-growing regions in the Chapare and Carrasco provinces of the Department of Cochabamba. Between 1976 and 1992, the populations of these provinces more than tripled (INE 2011).

As the Bolivia's masses were continually dispossessed and pushed out of legitimate forms of work, coca cultivation - and the production of its lucrative derivative cocaine - proved to be an economically viable means of employment for some. In the words of one coca grower from the Chapare: "Coca gave us life. With coca, we were able to raise our children. With yucca we got nothing. It doesn't cost anything and you cannot harvest it as much. Coca can be harvested every three months and with it you get more money" (personal interview). But with coca serving as the raw compound in the production of cocaine, coca growers in Bolivia became targets in the U.S. War on Drugs. Receiving aid, money, and training from the United States, the military worked in tandem with the Drug Enforcement Agency to end Bolivia's coca 'problem.' While an array of repressive techniques were used to coerce coca cultivators into 'voluntary' eradication projects, coca production and processing provided some Bolivians with a means to meet their livelihood needs and thus continued largely undeterred (Healy 1991; Léons and Sanabria 1997). While thousands of hectares of coca were eradicated each year, coca producers continued to expand the crop's cultivation in the 1980s and 1990s (Léons and Sanabria 1997: 187). Indeed, as in El Alto, the miner and campesino migrants of the Chapare slowly turned a space of marginalization into a common space of resistance.

In the Chapare, the organic link between miners and campesinos was forged as both sought to combat coca eradication projects. This convergence was displayed in the demands, discourse, and mix of tactics deployed by the coca growers. Mirroring the campesino struggles of 
the past, the coca growers called for greater autonomy from the state and an end to the external interventions of the United States. In addition, they frequently evoked the historical and cultural uses of coca to build support and mobilize people. In Bolivia, coca has been used for centuries as a stimulant, appetite suppressant, and ceremonial offering. Many Bolivians chew coca leaves daily or use it in tea. The traditional use of coca, combined with Bolivia's history of occupation by outsiders, allowed coca growers to portray themselves as defenders of Bolivian culture struggling for national sovereignty. As one cocalero stated:

The tropics of Cochabamba [the Chapare] is a coca producing zone. It has been a victim of imperialism under the pretext of fighting against drugs [...] Coca production is one thing, cocaine production is another [...] The production of the leaf in its natural state is not harmful to your health. It is medicinal, traditional (personal interview).

The cocaleros also used tactics traditionally employed by Bolivia's miners' unions. As another cocalero noted when talking about the actions taken after the passage of a law to increase coca eradication:

The organizations, the communities, and the federations, we began to organize ourselves. We became more united in order to resist the forces of repression [...] we would not accept a law that was unconstitutional [...] In 1988, we rejected the law. Then we blockaded roads, started mobilizations, marched, and had hunger strikes in La Paz with the COB [the Bolivian workers union] [...] Different movements united to defend the coca leaf in its natural state (personal interview).

In their struggles and protests, coca growers both took to the streets and constructed a coalition with other organizations and unions to bolster their cause.

For much of the 1980s and 1990s, groups such as FEJUVE and the coca growers largely directed their attention towards local issues resulting from accumulation by dispossession. In other words, they struggled to stave off the adverse effects resulting from dispossession not necessarily to stop or reverse these processes. As increasing numbers of people migrated to urban areas, organizations such as FEJUVE sought more just living and working conditions. As more people became dependent upon the coca sector to meet their basic livelihood needs, the coca growers organized against eradication. But as the needs of workers and campesinos merged and they began to struggle together in these spaces of marginalization, they began to more directly question who was benefitting from Bolivia's incorporation into the global economy. This became evident in Bolivia's social movement struggles to regain control over the country's hydrocarbon riches and eventually the state itself.

\section{From Struggles Against Dispossession to Struggles For Incorporation}

At the turn of the twenty-first century, Bolivia's marginalized masses began to change the focus of their struggles. For close to two decades, they had resisted policies such as the NEP and Plan de Todos and sought to insulate themselves from the effects. Such conflicts repeatedly played out in the everyday lives of many Bolivians and occasionally manifested into larger scale 
protests such as the Guerra del $\mathrm{Agua}^{3}$ in 1999 (Olivera and Lewis 2004). But in 2002, the marginalized masses directed their struggles to the benefits being gleaned from Bolivia's incorporation into the global economy as a natural gas supplier. Indeed, once Bolivia's workers and campesinos had come together, their struggles focused on the broader systemic causes that led to their marginalization.

The shift in the allied movements' focus became evident as a consortium of transnational energy firms made up of Repsol-YPF, British Gas (BG), and Pan-American Energy forwarded a plan to export the country's natural gas to the United States and Mexico (El Deber 2001). According to the transnational energy firms, new investments in the sector for the project would be greater than US\$2 billion (La Prensa 2002). The investments would allow Bolivia's natural gas to not only be sold to the United States and Mexico, but also to emerging markets in western Bolivia and northern Chile. ${ }^{4}$ According to several industry experts, the project would have increased the demand for Bolivia's natural gas and thus prices at which it would be sold ( $L a$ Razón 2002).

The project would have undeniably boosted the volume of Bolivia's natural exports and generated short-term revenue increases. However, the majority of natural gas exported by the consortium would have been sold for significantly less than the natural gas exported to Brazil at the time. As a representative of YPFB explained:

The selling price for Bolivia was going to be only US\$0.70 per million BTU. And we're getting US\$5 with our neighbors. So why should we sell all the way to the United States for peanuts? There's a funny thing about the oil industry, especially with natural gas. Do you know how they calculate the selling price? They discount all the transport costs and infrastructure built [...] So you've got to put a cryogenic plant at the seacoast of Peru or Chile. So you discount that cost. And then you discount the re-gasification plant in Mexico. Any you discount all the transport costs. And you discount all the investments. Then they tell you that you have to sell it for US\$0.70 [...] They take the selling price and then go back. They call it netback [...] It is 8,000 kilometers from Bolivia to the seacoast of the United States. If it was much further they would have told us that we had to pay them so we can export our gas (personal interview).

The sale of Bolivia's natural gas to the United States and Mexico would not have left the country completely empty-handed. The Bolivian state would have earned around US\$67 million a year in rents off of exports of $25 \mathrm{~mm} 3$ per day (El Deber 2002). However, for every US $\$ 1$ earned by the Bolivian state, the consortium of transnational energy firms spearheading the project would have earned US\$24, or approximately US\$1.608 billion a year (Opinión 2003).

In July 2002, a group of 21 organizations - including representatives of leftist political parties, the military, neighborhood organizations, workers unions, coca growers, and other campesino groups - began to call for the nationalization of Bolivia's hydrocarbons. Known as the Coordinadora Nacional de Recuperación y Defensa del Gas, the group started to mobilize

\footnotetext{
${ }^{3}$ The Water War.

${ }^{4}$ Natural gas can be used as a reduction agent in mining processes. At the time, the San Cristóbal mine in western Bolivia was drawing international interest, and investors were seeking to secure a share of Bolivia's natural gas to further develop the mine.
} 
Bolivia's marginalized masses to take to the streets and demand a share of the profits from the sale of the country's natural gas. In September 2003, the mobilizations escalated into what became known as the Guerra del Gas. Close to half a million people took the streets in the city of La Paz. After months of social unrest that resulted in over 70 deaths and 400 wounded, the social movements forced the resignation of then President Gonzalo Sánchez de Lozada. His vice president assumed the presidency and addressed the Coordinadora's demands by forwarding a referendum vote on the future of Bolivia's hydrocarbon sector (Kohl and Farthing 2006, 2012; Spronk and Webber 2007). Bolivians overwhelmingly voted to nationalize the country's hydrocarbons, reestablish YPFB, and increase the rents paid on oil and natural gas extraction activities.

Over the following years, the organic link between Bolivia's workers and campesinos became solidified in the formal political arena with the rise of the political party known as the Movimiento al Socialismo (MAS). While MAS began primarily as a party representing Bolivia's coca growers in the 1990s, its acceptance and promotion of an array of the demands of the marginalized eventually made it the dominant party through which the country's social movements entered the formal political arena (Harten 2011). By 2002, MAS representatives from throughout the country were elected to the national government, with the party taking 8 of 27 seats in the Senate and 27 of 130 seats in the Chamber of Deputies (CNE 2011). ${ }^{5}$ Of the 14 MAS deputies that were directly elected, four came from coca growing regions, six from mining areas, two from E1 Alto, and two from rural areas of La Paz.

In 2005, early elections were called after the Bolivian masses again took to the streets and forced the resignation of the interim president after he proved unable to satisfy the demands forwarded during the Guerra del Gas. In the elections, MAS made considerable gains throughout the country. It captured 12 seats in the Senate, 72 seats in the Chamber of Deputies, and Evo Morales won the presidential vote with an unprecedented simple majority, taking 53.74 percent of the vote. ${ }^{6}$ Following through on the marginalized masses' demands to nationalize Bolivia's hydrocarbon sector while also instituting an array of redistributive social programs, MAS and other electoral parties representing Bolivia's historically marginalized masses continued to gain power. In the elections for the assembly to rewrite Bolivia's constitution, MAS and its allied parties took 156 of 255 seats. The constitution guaranteed the state the rights to all of Bolivia's natural resource riches, and in 2009 it was approved by 61.4 percent of voters. In the general elections that followed later that year, Morales took 64 percent of the vote and MAS took a majority of seats in the both the Chamber of Deputies and the Senate (CNE 2011).

Taking control of the state, MAS oversaw a dramatic increase in the rents Bolivia obtained from its natural resources. After the nationalization of Bolivia's oil and natural gas, the government's take of rents more than tripled, increasing from US\$608 million in 2005 to US $\$ 1.85$ billion in 2010 (see Figure 3). The state used these rents to fund a number of social programs, increase the amount of money going to departmental and municipal governments, augment investment in the hydrocarbon exploration and extraction, and bolster its foreign reserves. Around 29.7 percent of the Bolivian population has directly benefitted from the social programs being funded by the country's hydrocarbon rents and the increasing amounts of money going towards local governments have allowed the municipalities in both El Alto and the

\footnotetext{
${ }^{5}$ The Chamber of Deputies is similar to the Congress in the United States.

${ }^{6}$ Since Bolivia's return to democracy in the 1980 s, no presidential candidate had received more than 35 percent of the vote and thus was forced to rule by striking power sharing agreements with other political parties.
} 
Chapare to spend more on education, health, and public infrastructure (Ministerio de Eocnomía y Finanzas Públicas 2011b). In addition, the government's investment in the hydrocarbon sector has resulted in a revitalization of YPFB and an increase in the number of workers employed by the state company and in the sector more generally. The MAS government has also satisfied some of the demands of the coca growers by expelling the U.S. Drug Enforcement Agency from the country, supporting the traditional uses of coca, and funding programs to develop alternative markets for coca.

Figure 3: Earnings from Hydrocarbon Taxes and Royalites in Bolivia, 1995-2010

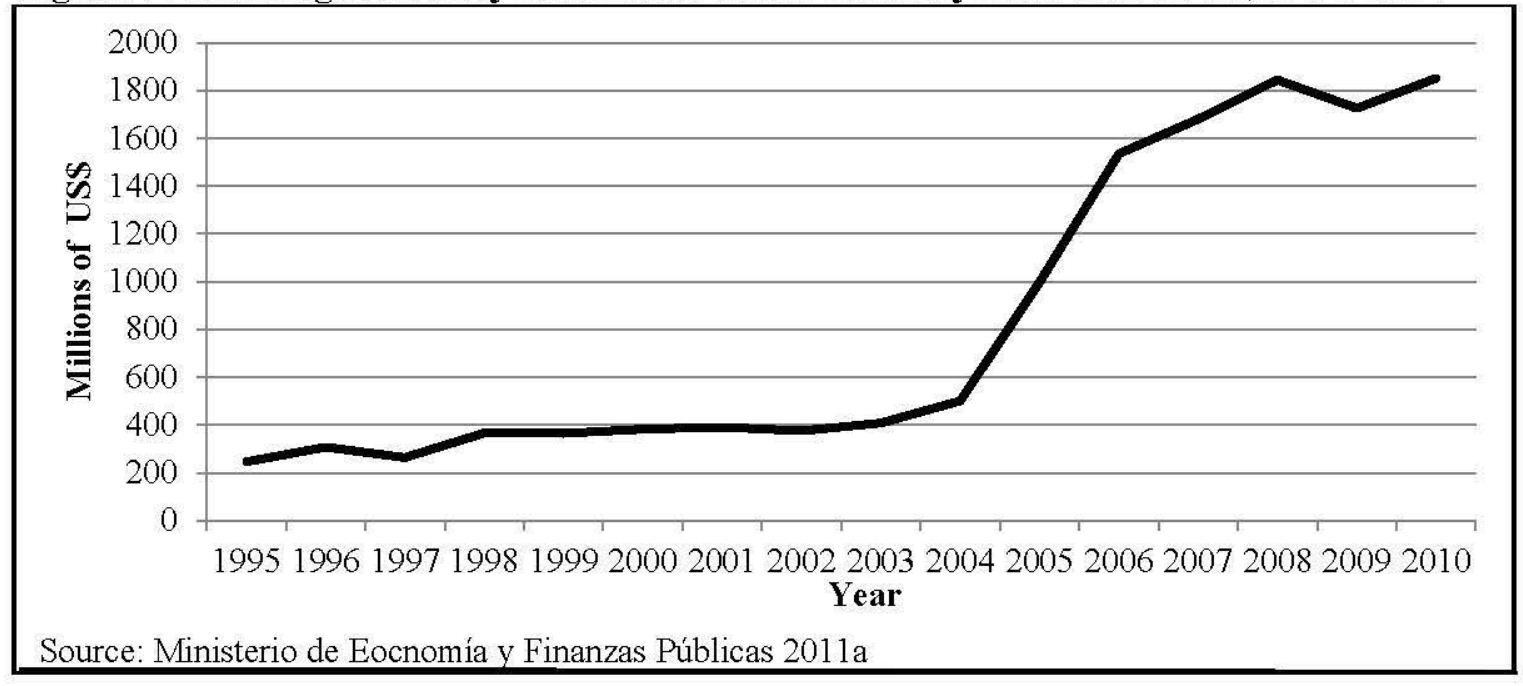

\section{Conclusion}

The uprisings in Bolivia at the turn to the twenty-first century provide a case through which to see the mechanisms and conditions behind the convergence of peasant and proletarian struggles. The struggles of Bolivia's peasants and workers did not merely come together in the face of a common oppressor. Instead, they came together as the changing forms and geographies of exploitation and dispossession throughout the globe brought them into common spaces - spaces of marginalization. Indeed, Bolivia's de- and reincorporation into the global economy dramatically affected the sociospatial organization within the country. As Bolivia moved from being predominantly a tin-producing country to being predominantly a natural gas-producing country, increasing numbers of people were excluded from global commodity circuits. This led to large-scale internal migration, as people flocked to places where they believed they could make a living. But in these places, Bolivia's marginalized masses did not simply disappear. Instead, the country's historically divided peasant and worker popular class factions converged. And as they did, they challenged the means through which Bolivia was incorporated into the global economy.

Scholars have often conceptualized the struggles by peasants and proletarians differently. Whereas peasants have often been seen to be struggling against dispossession, workers have often been seen to be struggling against exploitation. But at certain points in time, an organic link can form and the struggles of these two class factions can converge. In particular, as the means through which places are incorporated into the global economy shift, different class factions can 
simultaneously find their livelihood strategies disrupted and their once seemingly fractured interests can meld. The alignment of such class factions can present a formidable foe to powerful entities seeking to satisfy their labor and raw material demands without care for local places and peoples. Indeed, as shown in Bolivia, changing how a place is incorporated into the global economy without incorporating its people can result in a convergence of class struggle in a way that threatens the power and profits of the already powerful.

A convergence of peasant and proletarian struggles can produce a formidable force, but the long-term stability of such an alliance is delicate at best. In Bolivia, the interests of peasants and proletarians converged in places where the difference between peasants and workers eroded. In the Chapare, marginalized campesinos and miners became coca growers. In El Alto, marginalized campesinos and miners became workers in the informal urban economy. The convergence of peasant and proletarian interests in theses places created moments in which peasant and proletarian groups across the country aligned and solidified in the formal political arena under MAS, but the differences between the interests and demands of such class factions did not completely disappear.

Recent uprisings in Bolivia by both worker and peasant popular class factions illustrate just this. In the country's mining regions, workers in some of the largest mines have taken to the streets in struggles against exploitation to demand higher wages. In some places where pockets of more subsistence-based lifestyles still exist, peasant groups have protested against the construction of roads and other infrastructure that would alter the means through which they are incorporated into the country's and the region's economy. The Morales administration seems to see such protests as part of a vibrant democracy. Others see it as the weakening of the class coalition formed under MAS. Taking this into account, scholars studying the convergence of peasant and proletarian popular class factions should not only seek to understand how the organic link between these different groups is forged, but also how it can be maintained. 
References
Amin, Samir. 1974. Accumulation on a World Scale: A Critique of the Theory of Underdevelopment. New York and London: Monthly Review Press. 1977. Imperialism and unequal development. New York: Monthly Review Press.

Arbona, Juan Manuel. 2007. "Neoliberal ruptures: Local political entities and neighborhood networks in El Alto, Bolivia." Geoforum 38: 127-137.

Arrighi, Giovanni. 1979. "Peripheralization of the South Africa, I: Changes in Production Processes." Review III: 161-191.

-----. 1994. The Long Twentieth Century: Money, Power, and the Origins of Our Times. Verso: New York.

-----. 2005. "Hegemony Unravelling - 2." New Left Review 33: 83-116.

Arze, Carlos and Tom Kruse. 2004. "The Consequences of Neoliberal Reform." NACLA Report on the Americas 38(3): 23-28.

Ayub, Mahmood Ali and Hideo H. Hashimoto. 1985. The Economics of Tin Mining in Bolivia. Washington DC: The World Bank.

Budds, Jessica. 2004. "Power, nature and neoliberalism: the political ecology of water in Chile." Singapore Journal of Tropical Geography 25: 322-342.

Braudel, Fernand. 1984. Civilization and Capitalism, $15^{\text {th }}-18^{\text {th }}$ Century, Volume III: The Perspective of the World. New York: Harper \& Row.

Bunker, Stephen. 1984. "Mode of Extraction, Unequal Exchange, and the Progressive Underdevelopment of an Extreme Periphery: The Brazilian Amazon, 1600-1980." The American Journal of Sociology 89(5): 1017-1064.

Bunker, Stephen and Paul Ciccantell. 2005. Globalization and the Race for Resources. Baltimore, MD: Johns Hopkins University Press.

Burawoy, Michael. 1991. Ethnography Unbound: Power and Resistance in the Modern Metropolis. Berkeley: University of California Press.

Campodónico, Humberto. 2007. Gestión mixta y privada en la industria de hidrocarburos. CEPAL Serie de recursos naturales e infraestructura $\# 122$. Santiago, Chile.

CEPALSTAT. 2011. "Databases and Statistical Publications." United Nations European Commission for the Latin America and the Carribbean. Retrieved June 1, 2012 (http://www.eclac.org/estadisticas/bases/).

Contreras, Manuel. 1993. The Bolivian Tin Mining Industry in the First Half of the Twentieth Century. London: Institute of Latin American Studies Research Papers.

Contreras, Manuel and Mario Napoleon Pacheco. 1989. Medio Siglo de Minería Mediana en Bolivia, 1939-1989. La Paz, Bolivia: Biblioteca Minera Boliviana.

Corte Nacional Electoral (CNE). 2011. Accessed July 11, 2011 (http://www.cne.org.bo/).

E1 Deber. 2001. "Tres Petroleras Invertirán para Vender Gas a EE.UU." El Deber, 10 mayo.

-----. 2002. "Bolivia sólo recibirá \$US 67 millones por ano por la venta de gas a EE.UU." El Deber, 28 abril.

Fox, David. 1985. "Bolivian Mining, a Crisis in the Making." In Miners and Mining in the Americas, edited by W. Culver and T.C. Greaves. Manchester: Manchester University Press.

Gill, Lesley. 2000. Teetering on the Rim: Global Restructuring, Daily Life, and the Armed Retreat of the Bolivian State. New York: Columbia University Press.

Glassman, Jim. 2006. "Primitive accumulation, accumulation by dispossession, accumulation by 'extra-economic' means. Progress in Human Geography 30: 608-625 
Gobierno de Bolívia (GOB). 1985a. Decreto Supremo (DS) No 21060. August 29.

----. 1985b. Decreto Supremo (DS) No 21398. September 20.

Griess, Phyllis R. 1951. "The Bolivian Tin Industry." Economic Geography 27(3): 238-250.

Harten, Sven. 2011. The Rise of Evo Morales and the MAS. Zed Books: London.

Harvey, David. 2003. The New Imperialism. Oxford: Oxford University Press.

Healy, Kevin. 1991. "Political Ascent of Bolivia's Coca Leaf Producers." Journal of Interamerican Studies and World Affairs 31(1): 87-1

Hough, Phillip and Jennifer Bair. 2012. "Dispossession, Class Formation, and the Political Imaginary of the Colombia's Coffee Producers Over the Longue Durée: Beyond the Polanyian Analytic." Journal of World Systems Research XVIII(1): 30-49.

Hylton, Forest and Sinclair Thomson. 2007. Revolutionary Horizons: Past and Present in Bolivian Politics. Verso:London.

Instituto Nacional de Estadística (INE). 2011. "Bolivia: Población por Censos Según Departamento, Área Geográfica y Sexo, Censos 1950-1976-1992-2001." Retrieved February 3, 2011 (http://www.ine.gov.bo).

International Tin Research Institute (ITRI). 2011. Historical trends in tin usage. Retrieved June 1, 2012 (http://www.itri.co.uk/index.php?option=com mtree\&task=att download\&link $\mathrm{id}=49603 \& \mathrm{cf} \mathrm{id}=24)$.

Kaup, Brent. 2008. "Negotiating through Nature: The Resistant Materiality and Materiality of Resistance in Bolivia's Natural Gas Sector." Geoforum 39: 1734-1742

-----. 2013. "Transnational class formation and spatialities of power: the case of elite competition in Bolivia." Global Networks 13(1): 101-119.

Kohl, Benjamin and Linda Farthing. 2006. Impasse in Bolivia: Neoliberal Hegemony \& Popular Resistance. New York: Zed.

-----. 2012. "Material Constraints and Popular Imaginaries: The Extractive Economy and Resource Nationalism in Bolivia." Political Geography 31: 225:235.

La Prensa. 2002. "Por cada dólar que invierten, las petroleras ganan 10." 5 mayo.

La Razón. 2002. "Bolivia debe pelear por ganar el mercado de EE.UU. para el gas." La Razon, 12 abril.

Léons, Madeline Barbara and Harry Sanabria. 1997. "Coca and Cocaine in Bolivia: Reality and Policy Illusion." Pp: 169-194 in Coca, Cocaine, and the Bolivian Reality, edited by Madeline Barbara Léons and Harry Sanabria. Albany: State University of New York Press.

Martin, P. 2005. "Comparative Topographies of Neoliberalism in Mexico." Environment and Planning A 31: 203-220.

Marx, Karl. 1867. "Chapter Twenty-Six: The Secret of Primitive Accumulation" in Capital: Volume One. Retrieved August 30, 2010 (http://www.marxists.org/archive/marx/works/ $1867-\mathrm{cl} / \mathrm{ch} 26 . \mathrm{htm})$.

McCarthy, James. 2004. "Privatizing Conditions of Production: Trade Agreements as Neoliberal Environmental Governance." Geoforum 35: 327-341.

Ministerio de Economía y Finanzas Públicas. 2011a. Ingresos por Hidrocarburos en el Gobierno Gerneral. Retrieved September 13, 2012 (http://www.economiayfinanzas.gob.bo/ index.php?opcion $=$ com contenido\&ver $=$ contenido $\& \mathrm{id}=1304 \& \mathrm{id}$ item $=588$ ).

2011b. "Dossier I Semestre 2010." Retrieved May 30, 2011 (http://medios.economiayfinanzas.gob.bo/VTCP/documentos/dgpf/dossierfiscal/DOSSIE R-I SEMESTRE 2010.pdf). 
Moore, David. 2004. "The Second Age of the Third World: From Primitive Accumulation to Global Public Goods." Third World Quarterly 25(1): 87-109.

Morales, Juan Antonio. 1990. "Ajustes Estructurales en la Agricultura Campesina Boliviana." Debate Agrario 9: 121-162.

Morales, Juan Antonio and Justo Espejo. 1994. La Mineria y los Hidrocarburos en Bolivia. La Paz, Bolivia: Instituto de Investigaciones Socio Económicas.

O'Hearn, Denis. 2001. The Atlantic Economy: Britain, the US and Ireland. Manchester: Manchester University Press.

-----. 2005. "Cycles of Accumulation, Crisis, Materials, and Space: Can Different Theories of Change Be Reconciled?" Pp. 113-137 in Nature, Raw Materials, and Political Economy, edited by Paul Ciccantell and G. Seidman. San Diego: Elselvier.

Olivera, Oscar and Tom Lewis. 2004. Cochabamba! Water war in Bolivia. Boston: South End Press.

Opinión. 2003. "Las petroleras ganarán 24 veces más que Bolivia con la exportación del gas.” 10 octubre.

Perelman, Michael. 2000. The Invention of Capitalism. Durham, NC: Duke University Press.

Perreault, Thomas. 2006. "From the Guerra del Agua to the Guerra del Gas: Resource Governance, Neoliberalism and Popular Protest in Bolivia." Antipode 38(1): 150-172.

Prudham, S. 2007. "The Fictions of Autonomous Invention: Accumulation by Dispossession, Commodification and Life Patents in Canada." Antipode 39(3): 406-429.

Quijano, Anibal. 1970. Polo marginal y mano de obra marginal. Santiago: CEPAL.

-----. 1983. "Imperialism and Marginality in Latin America." Latin American Perspectives 10(2/3): 76-85.

Rojas, Bruno and Germán, Guaygua. 2002. Empleo en tiempos de crisis. Avances de Investigación 24. La Paz: CEDLA.

Rossell, Pablo. 1999. Diagnóstico socioeconómico de El Alto: distritos 5 y 6. La Paz: CEDLA.

Sachs, Jeffery. 1987. "The Bolivian Hyperinflation and Stabilization." The American Economic Review 77: 279-283.

Sanabria, Harry. 1999. "Consolidating States, Restructuring Economies, and Confronting Workers and Peasants: The Antinomies of Bolivian Neoliberalism." Society for the Comparative Study of Society and History 41(3): 535-562.

Scott, James. 1976. The Moral Economy of the Peasant: Subsistence and Rebellion in Southeast Asia. New Haven, CT: Yale University Press.

-----. 1985. Weapons of the Weak: Everyday Forms of Resistance. New Haven, CT: Yale University Press.

Seyler, Daniel. 1989. “'The Economy' in Bolivia: A Country Study.” Federal Research Division. Washington DC: Library of Congress.

Sokolvsky, Joan. 1985. "Logic, Space, and Time: The Boundaries of the Capitalist World Economy." Pp. 41-52 in Urbanization in the World Economy, edited by Michael Timberlake. Academic Press: New York.

Spronk, Susan and Jeffrey Webber. 2007. "Struggles against Accumulation by Dispossession in Bolivia: The Political Economy of Natural Resource Contention." Latin American Perspectives 34(2): 31-47.

United States Geological Society (USGS). 2011. "Tin Statistics." Retrieved June 1, 2011 (http://minerals.usgs.gov/ds/2005/140/tin.pdf). 
Wallerstein, Immanuel. 1979. The Capitalist World Economy. Cambridge: Cambridge University Press.

-----. 1989. The Modern World-System III: The Second Era of Great Expansion of the Capitalist World Economy, 1730-1840. San Diego: Academic Press.

-----. 2000. The Essential Wallerstein. New York: New Press.

Warshow, H.T. 1927. "Tin: An International Metal." Foreign Affairs 5(3): 482-489.

Webber, Jeffery R. 2011. From Rebellion to Reform in Bolivia: Class Struggle, Indigenous Liberation, and the Politics of Evo Morales. Chicago: Haymarket Books.

Wolf, Eric. 1969. Peasant Wars of Twentieth Century. New York: Monthly Review Press.

Wolford, Wendy. 2005. "Agrarian Moral Economies and Neoliberalism in Brazil: Competing Worldviews and the State in the Struggle for Land." Environment and Planning A 37: 241-261.

Wolpe, Harold. 1980: The Articulation of Modes of Production: Essays from Economy and Society. London: Routledge and Kegan Paul.

World Bank. 1983. Bolivia: Issues and Options in the Energy Sector. Report No. 4213-BO. Washington D.C.

Wright, Erik Olin. 1985. Classes. London: Verso. 